As-Syifaa Jurnal Farmasi Juli 2019; 11 (01): 75-81.

ISSN : 2085-4714

\title{
UJI EFEK EPITELISASI EKSTRAK DAUN EKOR NAGA (Rhaphidophora pinnata (L.f) Schott.) PADA TIKUS
}

\author{
Safriani Rahman, Andi Maulana Kamri
}

Fakultas Farmasi, Universitas Muslim Indonesia, Makassar

Email: safriani.rahman@umi.ac.id; andimaulanakamri@gmail.com

\begin{abstract}
Burns are damage to the skin due to contact with sources of heat and radiation. The stage of handling burns involves several phases, namely the inflammatory phase, proliferation and maturation. This study aims to determine the effect of epithelialization of ethanol extract of dragon tail leaves (Rhaphidophora pinnata (L.f) Schott.) In the process of wound healing. This research was conducted in an experimental laboratory and used rat test animals. 15 animals were divided into 5 groups consisting of group I (control) given Na.CMC, group II were given bioplacenton ointment, group III, IV and $V$ (group given) giving ethanol leaves Rhaphidophora pinnata extract. Giving is done twice a day for 14 days. The wound is made by inducing the back of a mouse with a hot plate of $1000 \mathrm{C}$ for 2 seconds.. The results of the study data are the average wound diameter and percent of wound reduction in statistics using oneway ANOVA and LSD follow-up test. Based on the results of the research that has been done, it can be concluded that the ethanol extract of dragon tail leaves has the effect of epithelialization in rats.
\end{abstract}

Key words: Epithelialization, burns, Rhaphidophora pinnata, inflammation.

\section{PENDAHULUAN}

Kulit adalah organ tubuh yang terletak paling luar dan membatasinya dari lingkungan hidup manusia. Kulit merupakan organ yang esensial dan vital serta merupakan cermin kesehatan dan kehidupan. Luka yang terjadi pada kulit akan sangat mempengaruhi kesehatan atau bahkan aktivitas seseorang, dikarenakan banyaknya saraf pada kulit yang dapat memicu rasa nyeri. Hal ini dapat terlihat apabila kulit mengalami luka bakar.

Luka bakar adalah kerusakan jaringan karena kontak dengan agen termal, kimiawi, atau listrik. Kerusakan jaringan akan diikuti reaksi kompleks dalam jaringan pengikat yang mempunyai pembuluh darah. Luka bakar hingga saat ini masih merupakan salah satu penyebab morbiditas dan mortalitas pada anak dan paling sering terjadi di rumah. ${ }^{1}$ Luka bakar jika tidak ditangani sesegera mungkin, maka akan menyebabkan berbagai komplikasi seperti infeksi, perdarahan, ketidakseimbangan elektrolit, sampai syok. ${ }^{2}$

Diperkirakan satu dari sekitar 3,5 juta orang akan mengalami luka bakar. ${ }^{3}$ World Health Organization (WHO) memperkirakan bahwa terdapat 265.000 kematian yang terjadi setiap tahunnya di seluruh dunia akibat luka bakar. $^{4}$

Prinsip penanganan dalam penyembuhan luka bakar diantaranya mencegah infeksi sekunder, memacu pembentukan jaringan kolagen dan membantu agar sisa sel epitel dapat berkembang sehingga dapat menutup permukaan luka. Penyembuhan luka merupakan proses yang kompleks dan melibatkan banyak sel. Reepitelisasi merupakan tahapan perbaikan luka yang meliputi mobilisasi, migrasi, mitosis, dan diferensiasi sel epitel. Regenerasi luka sangat dipengaruhi oleh reepitelisasi, karena semakin cepat proses reepitelisasi maka 
semakin cepat pula penyembuhan luka. Kecepatan penyembuhan luka dapat dipengaruhi oleh zat-zat yang terdapat dalam obat yang diberikan, jika obat tersebut mempunyai kemampuan untuk meningkatkan penyembuhan dengan cara merangsang lebih cepat pertumbuhan sel-sel baru yang terdapat pada kulit. ${ }^{5}$ Salah satu upaya terapi luka bakar adalah dengan pemberian bahan yang efektif mencegah inflamasi sekunder.

Terapi luka bakar melalui pemberian topikal dengan ekstrak herbal menjadi salah satu pilihan terapi yang dianggap ekonomis dan efektif. Terapi topikal dinilai efektif dalam mengatasi komplikasi luka bakar karena mudah diserap kulit dan dapat mempertahankan kelembaban kulit lebih lama. ${ }^{6}$ Meskipun dari segi medis, penggunaan herbal masih minim, tetapi tidak sedikit masyarakat juga beralih ke pengobatan tradisional yang sudah dikenal sejak dahulu ini karena dianggap sangat aman dan minim efek samping. Tujuan dari penelitian ini adalah untuk menentukan kemampuan epitelisasi ekstrak daun ekor naga (Rhaphidophora pinnata (L.f) Schott.) pada tikus.

Salah satu tanaman yang biasa digunakan untuk mengobati luka bakar adalah ekor naga (Rhaphidophora pinnata (L.f) Schott.). Bagian tanaman yang digunakan adalah daun. Daun ekor naga mengandung alkaloid, flavonoid, steroid, dan tannin. Flavanoid sebagai antiseptik dan antiinflamasi, juga berfungsi menghentikan pendarahan dan mempercepat proses penyembuhan luka. Saponin mempengaruhi kolagen dan menghambat produksi jaringan luka yang berlebih. Tanin membantu proses penyembuhan luka melalui peningkatan jumlah pembentukan pembuluh darah kapiler dan sel-sel fibroblast. Steroid menghambat enzim fosfolipase A2 yaitu enzim yang berperan dalam sintesis asam arakidonat yang kemudian akan menghasilkan mediator inflamasi. Daun ekor naga memiliki aktivitas antiinflamasi ekstrak etanol daun ekor naga dan mendapatkan hasil bahwa ekstrak etanol daun ekor naga dosis $62,5 \mathrm{mg} / \mathrm{kgBB}, 125$ $\mathrm{mg} / \mathrm{kgBB}$, dan $250 \mathrm{mg} / \mathrm{kgBB}$ memiliki aktivitas antiinflamasi dan dosis yang paling efektif adalah $125 \mathrm{mg} / \mathrm{KgBB}$. Berdasarkan hal tersebut di atas, maka akan dilakukan penelitian tentang uji efek epitelisasi ekstrak etanol daun ekor naga (Rhaphidophora pinnata (L.f) Schott.) pada tikus.

\section{METODE PENELITIAN}

Penelitian ini bertujuan untuk menentukan kemampuan epitelisasi ekstrak daun ekor naga (Rhaphidophora pinnata (L.f) Schott.) pada tikus. Bentuk penelitian ini adalah eksperimental laboratorium di Laboratorium Farmakologi dan Fitokimia Fakultas Farmasi Universitas Muslim Indonesia.

Hewan uji yang digunakan adalah tikus putih bergalur wistar yang sehat dengan bobot badan 100-200 gram yang berusia 2 bulan. Sampel yang digunakan dalam penelitian ini adalah daun ekor naga (Rhaphidophora pinnata (L.f). Sampel yang diperoleh dikumpulkan dan dicuci bersih dengan air mengalir. Kemudian sampel dipotong-potong kecil, lalu dikeringkan dengan cara diangin-anginkan pada ruang terbuka tanpa terkena sinar matahari langsung. Setelah kering, sampel dihaluskan. ${ }^{7}$

Ekstrak daun ekor naga (Rhaphidophora pinnata (L.f) dibuat dalam 3 dosis yaitu $100 \mathrm{mg} / \mathrm{KgBB}, 125 \mathrm{mg} / \mathrm{KgBB}$ dan $150 \mathrm{mg} / \mathrm{KgBB}$. Ditimbang secara berturut-turut 
100 mg; 125 mg dan 150 mg kemudian disuspensikan menggunakan $10 \mathrm{ml} \mathrm{NaCMC}$ $1 \%$.

\section{HASIL DAN PEMBAHASAN}

Penelitian ini diawali dengan pembuatan ekstrak daun tumbuhan ekor naga (Rhaphidophora pinnata (L.f) Schott) dengan metode maserasi menggunakan pelarut etanol 96\% sebanyak 3 L. Sampel daun tumbuhan ekor naga (Rhaphidophora pinnata (L.f) Schott) segar sebanyak $6,175 \mathrm{Kg}$ setelah dikeringkan diperoleh sebanyak 750 gram dan menghasilkan serbuk daun tumbuhan ekor naga (Rhaphidophora pinnata (L.f) Schott) sebanyak 300 gram, serta menghasilkan ekstrak kental sebanyak 20,5 gram. Penelitian ini menggunakan ekstrak kental daun tumbuhan ekor naga (Rhaphidophora pinnata (L.f) Schott) dengan 3 variasi dosis, salep bioplasenton sebagai pembanding, dan suspensi Na.CMC sebagai kontrol. Untuk melihat efektivitas ekstrak etanol daun tumbuhan ekor naga (Rhaphidophora pinnata (L.f) Schott) terhadap penyembuhan luka bakar derajat 2 dengan melihat kemampuan epitelisasi, maka diujikan ke hewan uji tikus. Hewan uji yang digunakan sebanyak 15 ekor yang dibagi dalam 5 kelompok perlakuan yaitu kelompok I (kontrol) diberikan Na.CMC, kelompok II (pembanding) diberikan salep bioplacenton, kelompok III, IV dan V (kelompok perlakuan) diberikan ekstrak etanol daun tumbuhan ekor naga (Rhaphidophora pinnata (L.f) Schott) dengan dosis secara berturut-turut $100 \mathrm{mg} / \mathrm{KgBB}, 125 \mathrm{mg} / \mathrm{KgBB}$, dan $150 \mathrm{mg} / \mathrm{KgBB}$. Pemberian dilakukan sebanyak 2 kali sehari selama 14 hari. Luka dibuat dengan cara menginduksi punggung tikus dengan plat panas $100^{\circ} \mathrm{C}$ selama 2 detik. Pengukuran diameter luka dilakukan pada hari ke- 3, ke- 7, ke-11, dan ke- 14 . Kemampuan epitelisasi daun tumbuhan ekor naga (Rhaphidophora pinnata (L.f) Schott) dapat ditentukan dengan parameter pengamatan secara makroskopik dan penurunan diameter luka bakar.

Pada pengamatan di hari ke- 3 dan ke 7 semua kelompok mengalami fase inflamasi. Proses ini ditandai dengan adanya: kemerahan yang disebabkan oleh adanya pembuluh kapiler yang mengalami dilatasi sehingga menyebabkan lumen menjadi kosong dan akan terisi darah dengan cepat. Selain itu luka mengalami edema atau pembengkakan dan terlihat basah. Hal ini disebabkan oleh bertambahnya jumlah cairan secara abnormal di kompartemen ekstraseluler bersamaan dengan percepatan pergerakan sehingga memungkinkan cairan yang cepat melalaui dinding pembuluh darah kejaringan peradangan molekul-molekul kecil lewat namun menahan protein-protein besar seperti plasma tetap berada dalam darah. ${ }^{8}$

Pada pengamatan hari ke 7 semua kelompok juga telah terbentuk keropeng, kecuali kelompok kontrol. Pada kelompok kontrol mengalami pembentukan nanah. Pembentukan keropeng menandakan proses proliferasi telah terjadi. Pada fase ini terjadi perbaikan dan proses epitelisasi oleh fibroblas yang berperan pada persiapan menghasilkan produk struktur protein yang akan digunakan selama proses rekonstruksi jaringan baru.

Pada pengamatan hari ke- 9, luka semua kelompok masih terjadi kemerahan. Pada hari ke 9 dan 10 kelompok pembanding dan perlakuan keropengnya sudah terlepas, sehingga luka tampak memerah dan basah. Pada hari ke-11, kelompok EEDEN 125 $\mathrm{mg} / \mathrm{KgBB}$, keropengnya sudah terlepas 
sehingga luka tampak memerah dan basah.

Pada kelompok pembanding luka sudah ditumbuhi rambut halus. Pada pengamatan hari ke- 14 , pada kelompok kontrol keropeng yang terbentuk sudah terlepas tetapi luka masih merah dan basah.

Pada kelompok pembanding, sebagian luka sudah mengalami penyembuhan yang ditandai dengan tumbuhnya rambut disekeliling luka, akan tetapi luka masih basah dan kemerahan. Pada kelompok $100 \mathrm{mg} / \mathrm{kgBB}$, terjadi pengecilan diameter luka yang disertai penyembuhan dimana ditandai dengan keropeng telah mengering dan terlihat luka juga sudah mengering. Pada kelompok $125 \mathrm{mg} / \mathrm{kgBB}$, luka masih terlihat basah. Sedangkan pada kelompok $150 \mathrm{mg} / \mathrm{kgBB}$ luka masih merah dan basah. Luka yang masih kelihatan merah dan basah masih menandakan bahwa proses inflamasi masih terjadi, sedangkan keropeng yang sudah mengering menandakan bahwa proses proliferasi masih terus berlangsung. Data rata-rata penurunan diameter luka bakar pada punggung tikus setelah pemberian sediaan uji dapat dilihat pada tabel 1 di bawah ini:

Tabel 1. Rata-rata diameter luka hewan uji setelah perlakuan

\begin{tabular}{cccccc}
\hline \multirow{2}{*}{ Perlakuan } & \multirow{2}{*}{ Awal } & \multicolumn{4}{c}{ Rata-rata diameter luka pada hari ke- } \\
\cline { 3 - 6 } & & $\mathbf{3}$ & $\mathbf{7}$ & $\mathbf{1 1}$ & $\mathbf{1 4}$ \\
\hline Kontrol (Na. CMC) & $2 \pm 0$ & $1,47 \pm 0,01$ & $1,85 \pm 0,24$ & $1,87 \pm 0,09$ & $0,83 \pm 0,67$ \\
Pembanding & $2 \pm 0$ & $1,79 \pm 0,66$ & $2,19 \pm 0,35$ & $0,59 \pm 0,11$ & $0,83 \pm 0,12$ \\
EEDEN 100 mg/KgBB & $2 \pm 0$ & $1,34 \pm 0,03$ & $1,37 \pm 0,12$ & $0,76 \pm 0,08$ & $0,28 \pm 0,03$ \\
EEDEN 125 mg/KgBB & $2 \pm 0$ & $1,29 \pm 0,15$ & $1,42 \pm 0,05$ & $0,78 \pm 0,06$ & $0,47 \pm 0,03$ \\
EEDEN 150 mg/KgBB & $2 \pm 0$ & $1,51 \pm 0,15$ & $1,31 \pm 0,16$ & $0,66 \pm 0,13$ & $0,25 \pm 0,03$ \\
\hline
\end{tabular}

Berdasarkan tabel di atas menunjukkan bahwa terjadi penurunan luas permukaan luka bakar pada semua kelompok perlakuan. Rata-rata penurunan diameter luka terjadi pada hari ke-3, tetapi pada hari ke-7 terjadi kenaikan diameter luka, kecuali kelompok EEDEN $150 \mathrm{mg} / \mathrm{KgBB}$. Hal ini diduga terjadi karena masih terjadi fase inflamasi. Pada hari ke 11 semua kelompok memperlihatkan penurunan diameter luka, kecuali kelompok kontrol. Pada hari ke-14 terlihat bahwa semua kelompok mengalami penurunan diameter luka, termasuk kelompok kontrol.

Untuk melihat perbedaan kemampuan epitelisasi pada tiap kelompok maka dihitung persen penurunan yang dapat dilihat pada tabel 2, di bawah ini :

Tabel 2. Persen penurunan rata-rata diameter luka tikus

\begin{tabular}{cc}
\hline PERLAKUAN & PERSEN PENURUNAN (\%) \\
\hline Na.CMC & 31 \\
Pembanding (bioplacenton) & 58,5 \\
EEDEN $100 \mathrm{mg} / \mathrm{kgBB}$ & 86 \\
EEDEN $125 \mathrm{mg} / \mathrm{kgBB}$ & 76,5 \\
EEDEN $150 \mathrm{mg} / \mathrm{kgBB}$ & 87,5 \\
\hline
\end{tabular}


Berdasarkan tabel di atas, dapat dilihat bahwa kelompok pemberian ekstrak daun tumbuhan ekor naga (Rhaphidophora pinnata (L.f) Schott) memberikan penurunan diameter luka yang baik jika dibandingkan dengan kelompok negatif yaitu sekitar 76,5$87,5 \%$, namun ekstrak daun tumbuhan ekor naga dosis $150 \mathrm{mg} / \mathrm{KgBB}$ memberikan persen penurunan yang lebih besar jika dibandingakan dengan 2 varian dosis ekstrak daun tumbuhan ekor naga lainnya. Sedangkan kelompok kontrol (Na.CMC) mengalami ratarata persentase penurunan luas luka sebesar $31 \%$. Untuk melihat perbedaan antar kelompok maka data persen penurunan tiap kelompok dilakukan uji statistik dengan metode one way anova. Berdasarkan hasil statistik tersebut, menunjukkan adanya perbedaan yang nyata antar kelompok. Untuk melihat perbedaan antar kelompok maka dilakukan uji lanjutan post hoc menggunakan LSD.

Hasil proses epitelisasi dapat dilihat dari gambar yang menunjukkan perbaikan luka pada tikus putih hingga hari ke-14 untuk setiap dosis dapat dilihat pada gambar 1 . Pada gambar tersebut terlihat perbaikan luka terjadi pada tikus (a) dan (b) lebih baik dibandingkan tikus (c). Dalam proses penyembuhan ini juga dipertimbangkan adanya infeksi pada tikus karena kondisi lingkungan yang rentan menunjang perkembangan bakteri pada luka.
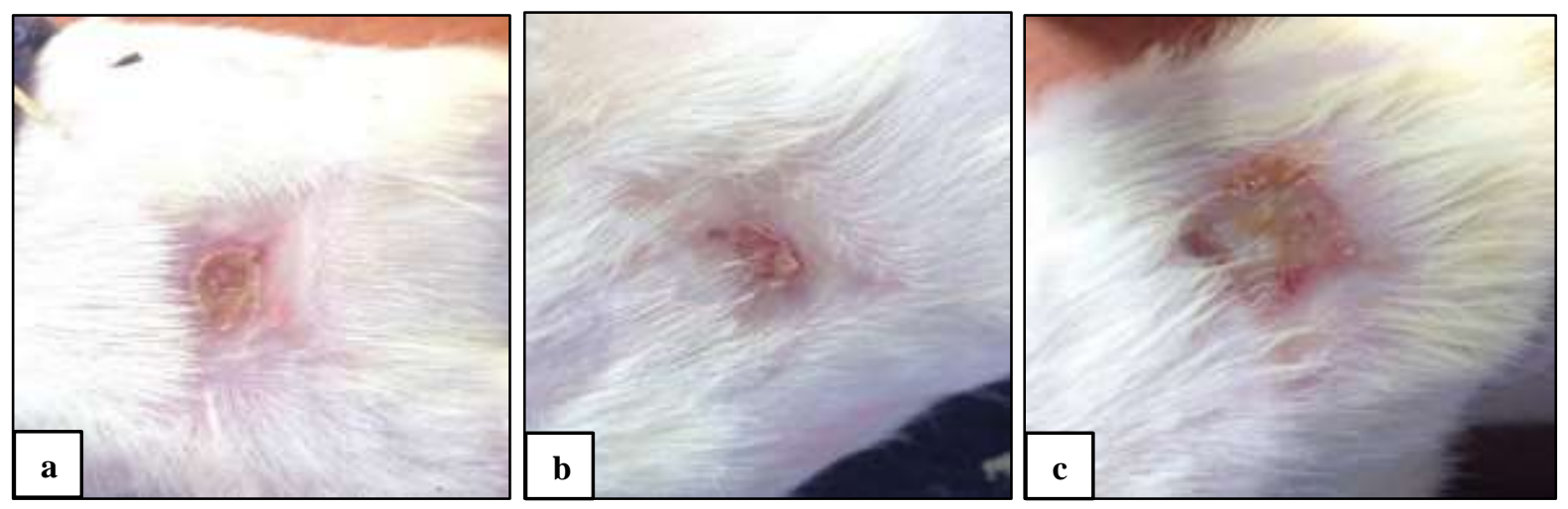

Gambar 1. Perbaikan luka bakar pada (a) tikus dengan dosis $100 \mathrm{mg} / \mathrm{kgBB}$, (b) tikus dengan dosis $125 \mathrm{mg} / \mathrm{kgBB}$, (c) tikus dengan dosis $150 \mathrm{mg} / \mathrm{kgBB}$

Luka bakar adalah rusaknya struktur dan fungsi anatomi kulit yang disebabkan oleh agen termal seperti kontak dengan api, cairan panas, dan benda panas. Luka bakar yang terbentuk mengalami perbaikan jaringan sebagai respon alami tubuh. Salah satu bentuk respon perbaikan jaringan yang terjadi yaitu epitelisasi. Epitelisasi merupakan proses pembentukan epitel baru pada jaringan luka. ${ }^{9}$ Penelitian ini dilakukan dengan tujuan untuk menentukan kemampuan epitelisasi ekstrak daun ekor naga (Rhaphidophora pinnata (L.f)
Schott.) pada tikus. Pada ekstrak Rhaphidophora pinnata mengandung tanin, saponin, flavanoid, alkaloid, triterpenoid, dan glikosida. Flavanoid dan beberapa jenis fenolik lainnya memiliki efek dalam penghambata proliferasi sel yang tentunya akan berpengaruh dalam proses perbaikan sel. ${ }^{10}$

Hasil menunjukkan adanya penurunan diameter luka yang terjadi pada kelompok kontrol diduga terjadi karena mekanisme kontrol tubuh yang memberikan respon terhadap adanya kerusakan sel yang terjadi. 
Sedangkan pada kelompok perlakuan diduga terjadi karena adanya kandungan kimia alkaloid, flavonoid, saponin, tanin, triterpenoid/steroid. Flavonoid dengan mekanisme kerja menghambat proses kemotaksis serta menurunkan jumlah leukosit. Sehingga menurunkan adhesi leukosit pada jaringan endotel mengakibatkan penurunan respon inflamasi.

Senyawa steroid dapat menghambat enzim fosfolipase A2 yaitu enzim yang berperan dalam sintesis asam arakidonat yang kemudian akan menghasilkan mediator inflamasi. Kandungan saponin yang terdapat pada tumbuhan ini dapat mempercepat proses penyembuhan luka dengan cara meningkatkan faktor pertumbuhan endotel vaskular dan interleukin yang merupakan salah satu mediator inflamasi. Mediator ini mampu mneginduksi makrofag menuju daerah yang mengalami cedera dan mempercepat proses penyembuhan. ${ }^{11}$

Dari hasil uji statistik menunjukkan bahwa kelompok perlakuan memiliki efek yang berbeda nyata dengan kelompok kontrol (Na.CMC). hal ini berarti kelompok kontrol dengan kelompok perlakuan memiliki aktivitas yang berbeda dalam hal epitelisasi. Sedangkan kelompok perlakuan EEDEN 100 $\mathrm{mg} / \mathrm{KgBB}$ dan EEDEN $125 \mathrm{mg} / \mathrm{KgBB}$ memiliki efek yang sama dengan kelompok pembanding (bioplacenton). Hal ini berarti antara kelompok tersebut memiliki aktivitas yang sama dalam hal epitelisasi.

\section{KESIMPULAN}

Hasil penelitian yang telah dilakukan dapat disimpulkan bahwa ekstrak etanol daun ekor naga (Rhaphidophora pinnata (L.f) Schott.) memiliki afek epitelisasi pada tikus. Ekstrak etanol daun ekor naga dosis 100 $\mathrm{mg} / \mathrm{KgBB}$ dan $125 \mathrm{mg} / \mathrm{KgBB}$ yang secara statistic memiliki efek yang bermakna dalam proses epitelisasi.

\section{DAFTAR PUSTAKA}

1. Negara RFK, Ratnawati R, Dewi DSLI. Pengaruh Perawatan Luka Bakar Derajat II Menggunakan EKstrak Etanol Daun Sirih Terhadap Peningkatan Ketebalan Jaringan Granulasi pada Tikus Putih (Rattus norvegicus) Jantan Galur Wistar. Majalah Kesehatan FKUB. 2014;1(2):8694.

2. Handayani F, Siswanto E, Pangesti LA. Uji Aktivitas Ekstrak Etanol Gambir (Uncaria gambir Roxb.) Terhadap Penyembuhan Luka Bakar Pada Kulit Punggung Mencit Putih Jantan (Mus musculus). Jurnal Ilmiah Manuntung. 2015;1(2):133-139.

3. Sheridan RL. Burns: A Practical Approach To Immediate Treatment and Long Term Care. London: Manson Publishing, 2012.

4. WHO, 2014. Burns. [Online] Available at: HYPERLINK

"http://www.who.int/mediacentre/fact sheet/fs365/en/"

http://www.who.int/mediacentre/fact

sheet/fs365/en/\# [Accessed 20 Juni 2018].

5. Prasetyo BFI, Wientarsih dan Priosoeryanto BP. Aktivitas Sediaan Gel Ekstrak Batang Pohon Pisang Ambon Dalam Proses Penyembuhan Luka Pada Mencit. Jurnal Veteriner. Bogor: Fakultas Kedokteran Hewan, Institut Pertanian Bogor, 2010.

6. Isrofah, Sagirah, Afandi M. Efektivitas Salep Ekstrak Daun Binahong (Andredera cordifolia (Ten)Steenis) Terhadap Proses Penyembuhan Luka Bakar Derajat 2 Termal pada Tikus Putih (Rattus norvegicus). Muhammadyah Journal Of Nursing. 2015;2(1):27-39.

7. Kemenkes RI. Suplemen I Farmakope Herbal Indonesia. Jakarta : Kementerian Kesehatan Republik Indonesia, 2010.

8. Yudhi P. Perbedaan Jumlah Fibroblas di Sekitar Luka Insisi pada Tikus yang Diberikan Infiltrasi Penghilang Nyeri Levobupivakain yang Tidak Diberi Levobupivakain (Tesis). Semarang: 
Fakultas MIPA, Universitas Diponegoro, 2007. pp. 15-40.

9. Balqis $U$, Rasmaidar and Marwiyah. Gambaran histopatologis penyembuhan luka bakar menggunakan daun kedondong (Spondias dulcis F.) dan minyak kelapa pada tikus putih (Rattus norvegicus). Jurnal Medica Veterinaria. 2014;8(1):3136.

10. Masfria, Sumaiyah, Dalimunthe A.. Antimutagenic Activity of Ethanol Extract of Rhaphidophora pinnata (Lf) Schoff Leaves on Mice. Sci Pharm. 2017;85(1):7.

11. Kulsum U, Hendari R, and Chumaeroh S. Pengaruh pemberian gel kombinasi ekstrak getah papaya (Carica papaya L) dan ekstrak daging lidah buaya (Aloe vera) terhadap proses penyembuhan ulkus traumatikus pada male wistar rats yang menderita diabetes mellitus. ODONTO Dental Journal. 2015;2(2):4146. 